\title{
The Influence of Carbon and Silicon Content in Ductile Iron on Shrinkage Creation for Castings with Different Wall Thickness
}

\author{
Martin Conev ${ }^{1}$, Iveta Vasková ${ }^{1}$, Martina Hrubovčáková1, Štefan Eperješi ${ }^{1}$, Alena Pribulová ${ }^{1}$ \\ ${ }^{1}$ Institute of Metallurgy, Faculty of Metallurgy, Technical University in Košice, Slovakia, E-mail: martin.conev@tuke.sk, \\ iveta.vaskova@tuke.sk,martina.hrubovcakova@tuke.sk, stefan.eperjesi.2@tuke.sk, alena.pribulova@tuke.sk
}

In modern times there are increasing requirements for quality of products in every part of manufacturing industry. In foundry industry it is not different and from the point of view of quality the most dangerous are hiden casting defects, such as shrinkage cavities. That is why a lot of foundries are researching, how to increase the efficiency of producing castings. This experimental work is dealing with search of the influence of carbon and silicon content in ductile iron on shrinkage creation. In the experimental part there is introduced the production process of test castings and results of ultrasound non destructive method. The object of this paper was to determine the influence of two main alloying elements of ductile cast iron on shrinkage creation with preserving specific strength of mould, which also has an impact on shrinkage creation.

Keywords: Ductile iron, chemical composition, shrinkage, ultrasound.

\section{References}

[1] NOVA, I., MACHUTA, J. (2014). Monitoring Methods the Properties and Structure of Grey Iron Castings. In: Manufacturing Technology. Vol. 14, No. 2, pp. 223 - 228. UJEP. Czech Republic.

[2] VAŠKO, A. (2013). Influence of heat treatment on the microstructure of synthetic nodular cast irons. In: Manufacturing Technology. Vol. 13, No. 1, pp. 115 - 119. UJEP. Czech Republic.

[3] GEDEONOVÁ, Z., JELČ, I. (2000). Metalurgia liatin, Košice.

[4] NĚMEC, M., BEDNÁř, B., STUNOVÁ, B. (2009). Teorie slévání, ČVUT, Praha.

[5] Karl-Heinrich GROTE, K.H., ANTONSSON, E.K. (2009). Springer Handbook of Mechanical Engineering, Springer, Berlin.

[6] KARSAY, S.I. (1976). Ductile Iron vol. 1 - Production. QIT - Fer et Titane Inc, Montreal.

[7] HAMPL, J. (2013). Metalurgie slévárenských litin, Ostrava.

[8] GEDEONOVÁ, Z. (1990). Teória zlievárenských pochodov, Alfa, Košice.

[9] STN 421240 (1964). Casting defects. Terminology and classification of defects.

[10] SKALAND, T. (2003). Ductile iron shrinkage control through graphite nucleation and growth. In: International Journal of Cast Metals Research, Volume 16, Issue 1, pp. 11-16. United Kingdom.

[11] SOIVIO, K., ELMQUIST, L. (2013). Influence of inoculation on shrinkage defects in spheroidal graphite cast iron. In: International Journal of Cast Metals Research, Volume 26, Issue 4, pp. 220-227. United Kingdom.

[12] KANNO, T. (2008). Effect of pouring temperature, composition, mould strength and metal flow resistance on shrinkage cavities in spheroidal graphite cast iron. In: International Journal of Cast Metals Research, Volume 21, Issue 1 - 4, pp. 2 - 6. United Kingdom.

[13] CHISAMERA, M., RIPOSAN, I., STAN, S., TOBOC, P., SKALAND, T., WHITE, D. (2011). Shrinkage evaluation in ductile iron as influenced by mould media and inoculant type. In: International Journal of Cast Metals Research, Volume 24, Issue 1, pp. 28 - 36. United Kingdom.

[14] LIU, Z., LIU, X. (2014). Study on a New Technique to Prevent Shrinkage defects of Alloy Ductile Iron Crankshaft. In: International Conference on Material and Environmental Engineering, ICMAEE 2014.

[15] EBERT, B., ZEMÁNEK, R. (2006). Targeted inoculation of cast iron particularly heavy castings made from material GJS 400-18-LT. In: Slévarenství, Vol. 2-3. Czech Republic.

[16] FLORES, C., RAMOS, E., RAMÍREZ, M., GONZÁLES, C. (2010). Applied pressure control risering of a ductile iron sand casting, In: Procceedings of METAL 2010, Tanger, s.r.o., Ostrava.

[17] KREIDEL, M. (2011). Ultrazvuková defektoskopie, Starmans electronics, Praha. 
[18] ANDRŠOVÁ, Z., SKRBEK, B. (2012). The use of magnetic and ultrasonic structuroscopy for inspection of ADI/AGI castings. In: Manufacturing Technology. Vol. 12, No. 13, pp. 93 - 97. UJEP. Czech Republic

[19] SKRBEK B. (2001). Ultrasonic testing of internal defects of castings from spheroidal graphite cast iron - comparison with radiographic methods. In: Slévárenství, Vol. 7-8. Czech Republic.

[20] VRZGULA, P., FATURÍK, M., MICIAN, M. (2014). New Inspection Technologies for Identification of Failure in the Materials and Welded Joints for Area of Gas Industry. In: Manufacturing technology. Vol. 14, No. 3, pp. 487-492. UJEP. Czech Republic.

[21] BELAN J. (2010). Identification of cast iron type with using of NDT methods. In: Archives offoundry engineering. Vol. 10, No. 1. Poland.

[22] NOVA, I., MACHUTA, J. (2014). Monitoring Methods the Properties and Structure of Grey Iron Castings. In: Manufacturing Technology. Vol. 14, No. 2, pp. 223 - 228. UJEP. Czech Republic.

[23] DIN EN 12680 - 1 (2003). Gießereiwesen, Ultraschallprüfung. 